\title{
"To have, to hold, from this day forward": understanding current practice regarding the retention of trial participants
}

\author{
Anne Daykin ${ }^{1}$, Athene Lane ${ }^{1 *}$, Carrol Gamble ${ }^{2}$, Anna Kearney $^{2}$, Jane Blazeby ${ }^{1}$, Mike Clarke ${ }^{3}$, Paula Williamson ${ }^{2}$, \\ Ali Heawood ${ }^{1}$
}

From 3rd International Clinical Trials Methodology Conference

Glasgow, UK. 16-17 November 2015

\section{Background}

Inadequate retention can introduce bias and reduce the power of a trial. The aim of this qualitative study was to elicit detailed accounts from trialists regarding strategies used to enhance retention in clinical trials.

\section{Methods}

A purposive sample of five trials was selected from the Health Technology Assessment Portfolio of currently funded trials. Semi-structured interviews explored methods utilised by trial teams when collecting data and retaining participants. The data was analysed thematically using techniques of constant comparison.

\section{Findings}

Clear and cohesive definitions of retention were given. However, there was less agreement about the concept of 'withdrawal' from a trial. More experienced trialists emphasised different levels of withdrawal and were happy to negotiate with participants in order to at least collect primary outcome data. Novice trialists presumed the participants wanted to withdraw from all aspects of the trial and made no further contact with them.

Research Nurses used their interpersonal skills to motivate participants to remain in their trials. This required time not routinely acknowledged within the funding of trials.

Participants described proactive and reactive approaches to retention. Proactive approaches involved anticipated and considered strategies, both formal and informal, to maintain retention. Conversely, reactive approaches were

${ }^{1}$ University of Bristol, Bristol, UK

Full list of author information is available at the end of the article typified by unanticipated and spontaneous strategies, some formalised others informal, developed in response to retention problems during the trial.

\section{Conclusion}

The experience of trialists influences their actions during the retention of patients. Recommendations from this study highlight the need for sharing proactive approaches to retention that will benefit the trials community.

\section{Authors' details \\ ${ }^{1}$ University of Bristol, Bristol, UK. ²University of Liverpool, Liverpool, UK. ${ }^{3}$ Queen's University, Belfast, UK.}

Published: 16 November 2015

doi:10.1186/1745-6215-16-S2-P104

Cite this article as: Daykin et al: "To have, to hold, from this day

forward": understanding current practice regarding the retention of trial participants. Trials 2015 16(Suppl 2):P104.

Submit your next manuscript to BioMed Central and take full advantage of:

- Convenient online submission

- Thorough peer review

- No space constraints or color figure charges

- Immediate publication on acceptance

- Inclusion in PubMed, CAS, Scopus and Google Scholar

- Research which is freely available for redistribution

Submit your manuscript at www.biomedcentral.com/submit
() Biomed Central 